\section{LULA'S BRAZIL IN AFRICA: \\ CULTURAL DIPLOMACY AS \\ AN INSTRUMENT OF SOFT \\ POWER}

POR Mathilde Chatin

\section{ABSTRACT}

During the Lula government, cultural diplomacy was used as an important instrument to exercise soft power and to carve out a leading role for Brazil in international politics. The range of Brazil's partners in the domain of cultural diplomacy widened as Brazil's relations with the global South and the African continent expanded, as part of a broader strategy to obtain a more prominent role in global affairs. This paper investigates this movement of greater Brazilian activism in the area of cultural diplomacy on the African continent as an illustration of the political significance of South-South relations and of Brazil's attempt to achieve its goal to be a global player through soft power.

\section{RESUMO}

Durante o Governo Lula, a diplomacia cultural foi utilizada como importante instrumento para que o Brasil exercesse poder brando ("soft power") e assumisse um papel de liderança na política internacional. O número de parceiros do Brasil no campo da diplomacia cultural foi ampliado, enquanto suas relações com o Sul global e o continente africano se expandiram, como parte de uma estratégia mais abrangente em assuntos globais. O presente artigo investiga esse movimento de maior ativismo na área da diplomacia cultural no continente africano como ilustração da importância das relações Sul-Sul e da tentativa do Brasil de atingir seu objetivo de tornar-se um ator global através do poder brando.

\section{PALAVRAS CHAVES}

Brasil, diplomacia cultural, África

\title{
KEYWORDS
}

Brazil, cultural diplomacy, Africa

\footnotetext{
'Mathilde Chatin holds a PhD in International Relations from King's College London. She has been a fellow at the BRICS Policy Center in Rio de Janeiro and a visiting scholar in the Department of International Relations of the University of São Paulo. Her publications include : Chatin M. (2018) «Sous-marin à propulsion nucléaire: dissuasion, développement et autonomie technologique ». Champs de Mars 30, pp.285-293. Chatin M. (2016) "Brazil: analysis of a rising soft power » Journal of Political Power 9(3), pp.369-393.
} 
Cultural diplomacy was given an expressive impulse within a wider project to affirm Brazil on the international scene. During the Lula government, actions of cultural diplomacy were revitalized as a diplomatic instrument, revealing the greater attention given to the importance of the cultural factor to Brazil's foreign policy (Leite Lessa et al. 2011; Machado 2012). It is significant that the internationalization of culture was one of the three priorities adopted by the Ministry of Culture. The conduct of the Lula administration's cultural policy abroad puts forward the increase of Brazil's presence in Africa, and the extent of these actions to adjust to the priority given by the government to the African continent (Bijos and Arruda 2012). In fact, President Lula made the strengthening of South-South links one of Brazilian foreign policy's most important axes (Buss and Ferreira 2012; Smits 2014). This paper will argue that Brazil's cultural diplomacy in Africa shows how the country "touts soft power propelled by diplomatic prowess to gain international stature" (Brimmer 2014). In fact, soft power has been one of the trademarks of Brazilian foreign policy to wield global influence and a key base for Brazil's rise as an emerging power (Mares 2016).

\section{Soft power and cultural diplomacy}

Soft power is "the ability to get what you want through attraction rather than coercion or payments" and the related "ability to shape the preferences of others"; command power associated with economic and military power is thus distinguished from the co-optive or "soft" power (Nye 2004). The soft power of a country rests upon "the attractiveness of its culture, the appeal of its domestic political and social valves, and the style and substance of its foreign policies" (Nye 2011 ). Depicting the Brazilian viewpoint on soft power, Ambassador Celso Amorim, former Minister of External Relations and Defence, underscored "the use of culture and civilization, not of threats (and) force" (Lustig 2010).

As such, cultural diplomacy is one of the instruments mobilizing culture as a resource to produce attraction (Nye 2010). Cultural diplomacy is defined as the "exchange of ideas, information, art and other aspects of culture among nations and 
their peoples in order to foster mutual understanding" (Cummings 2003). Similarly, the Brazilian Ministry of External Relations conceives cultural diplomacy as "an important instrument to bring peoples together, contributing to (...) the establishment of cultural and linguistic bonds. It is also a tool to stimulate political and economic dialogue, for it fosters mutual understanding and creates trust, interest and respect between nations" (MER n.d.). The dissemination of culture aims to strengthen relationships, stimulate socio-cultural cooperation, improve relations between the people of the international community and promote national interests. In fact, art and culture are in the forefront of the promotional efforts of many countries, which recognize that showing their cultural heritage provides them with an opportunity to create a positive image and help the rest of world to understand and value them better, thus helping to achieve their political aims (Vidal Pérez 2014).

\section{Brazil's soft power}

Consensus exists on the essentially soft nature of Brazil's power: Brazil is both "a good example of what is called soft power" and "the state where soft power plays a primary role" (Gardini 2015; Théry 2014; Bruk 2013). Brazilian Army Colonel Sales Bonfim remarked: "I believe Brazil has soft power (...) this is what we have that has most value in the International System" (Rodriguez 2013). Also, former President Fernando Henrique Cardoso claimed: "the important contribution Brazil has to give to the construction of the current international order should occur through soft power" (Cardoso 2011). Commenting on the link between soft power and diplomacy, Ambassador Celso Amorim estimated that, while soft power pre-exists and diplomacy draws on it, soft power is the proper way for diplomacy to be exercised (Lima 2015). Writing to the author, Nye argued that Brazil has increased in power because of its soft power; he indeed affirmed that, in terms of soft power, Brazil has adopted a foreign policy designed to project a positive image worldwide (Chatin 2018; Lee 2011; Nye 2015). By resorting to the possibilities offered by the promotion of its soft power at an international level, Brazil has strengthened its external action and 
increased its global influence (Dytz Filho 2014). Brazil exercises its soft power in an effort to carve out a leading role in world politics, and has thus maneuvered to achieve its goal to be a global player through soft power (Marsili 2015; Satana 2016). In fact, exerting influence by promoting soft power has been an important goal of Brazil's soft policy to strengthen its political capital, global influence, prestige and visibility (Soares Castro 2013). Kalil and Braveboy-Wagner posited that, in the 21 st century, Brazil's primary means of influence has been based on soft power, which is thus the key to grasping how Brazil has played a leading role and risen in the international system as a global power (Kalil and Braveboy-Wagner 2016). Two foreign diplomats interviewed by Chatin (2018) recognized that Brazil has founded its global projection on elements constitutive of a soft power, and that its abundance of soft power has been a unique aspect of its rise.

\section{Closer ties between Brazil and Africa}

Although Brazil has a long and complex history of ties to Africa dating back to the colonial era, the country gave greater attention to its African partners, as part of a broader strategy to expand relations with the global South, when the Workers' Party-led government of Luiz Inácio da Silva (2003-2010) came to power' (Abdenur and Marcondes 2016). Under President Lula, the political significance of South-South relations has been considered an integral aspect of Brazil's foreign policy agenda and an instrumental component to assume a more prominent role in global affairs (Marques and Spanakos 2014; Seabra 2014). Two foreign diplomats interviewed by Chatin (2018) recognized that President Lula asserted the "soft Brazil brand" of building the South-South relationship: South-South cooperation, which has been a political aim and an important component of Brazilian foreign policy under President Lula, was clearly used to increase Brazil's global influence.

\footnotetext{
'The emphasis put on South-South dialogue by Brazilian diplomacy under Lula has been viewed as a return to the policy adopted during the Cold War, when South-South relations were integrated into Brazil's foreign policy.
} 
In the 2000s, Africa thus gained strategic importance in Brazil's foreign policy and ties deepened considerably. Though still a small share of total Brazilian trade, commercial exchanges with Africa grew from US\$ 4.2 billion to U\$27.6 billion from 2000 to $2011^{2}$. President Lula carried out active presidential diplomacy on the African continent, making 12 visits to 29 African countries during his two terms. Brazil doubled its diplomatic presence in Africa from 17 to 37 embassies, surpassing traditional powers like Great Britain, to rank among the countries with most diplomatic representation on the African continent (Stolte 2014). A foreign diplomat interviewed by Chatin (2018) recognized that Brazil's "presence in Africa has enabled Brazil to strengthen and expand its soft power to other parts of the world".

The Lula government was marked by closer relations with countries that shared some cultural identity with Brazil (Bijos and Arruda 2012). According to the Lula Institute, "Brazil's relations with African governments and peoples stopped being only a sequence of isolated episodes and came to occupy in Brazil's diplomatic agenda space proportional to Africa's importance in the country's history, culture and identity" (Lula Institute 2017). Brazil relied on its historical and cultural links to the African continent to give a new dimension to its cooperation, and it is in this framework that the use of culture as an instrument of foreign policy has been highly pertinent. Brazilian authorities seemed to be driven by the idea that to build Brazil's power status, the country had to affirm itself as a reference mobilizing culture and other immaterial resources. In this perspective, the African continent appeared, in their eyes, as a propitious terrain, not only because Brazil counts the greatest number of citizens of African origin outside Africa, but also because Brazilian culture enjoys certain popularity there due to the growing interest that its music, football and telenovelas spark (Santander 2011 ). In terms of foreign policy, culture was used as a tool to create identity bonds and roots recognition, strengthening closeness to countries and regions strategic to the development of South-South cooperation, and to consolidate historical and cultural ties between Brazil and Africa (Leite Lessa etal. 2011).

\footnotetext{
2 For some, Brazil masked its capitalist expansion in Africa through rhetoric and solidarity to advance new opportunities for Brazilian economic actors, and thus its self-serving economic and commercial interests.
} 


\section{Brazilian identity: African heritage and cultural diversification}

For Brazil, closer ties to Africa under President Lula's government had a dimension linked to identity, as explained by Ambassador Celso Amorim: "there are two objectives in this strategy of approximation concerning Africa: an effort of realization of its universalist vocation and the safeguard of its national identity in the elaboration of its external policy" (Amorim 2010). Brazil's cultural policy towards Africa should be considered as part of the Lula government's strategy to celebrate the country's cultural diversity by notably underlining the special place of AfroBrazilian culture. One of the most notable initiatives taken by Brazil was the adoption of the law 10639/2003, which turned compulsory the teaching of African and AfroBrazilian history and culture in Brazil, making evident the will of the Lula government to revive the country's African roots through the education system. The inauguration of different museums dedicated to the Afro-Brazilian identity and culture, like that of the Afro-Brazil museum in São Paulo in 2004, also illustrates the importance granted by Brazilian authorities to the promotion of Brazil's African heritage (Falomir Lockhart and Lamine Sarr 2015). Under the Lula administration, cultural diversity, which was one of the main axes of cultural diplomacy, became a central element used to diminish international asymmetries resulting in hegemonic models (Bijos and Arruda 2012). Value was given to the mixed character of the Brazilian culture by recognizing the importance of Afro-descendants' contribution to the national history and culture, projecting an image abroad that amplified the attention given to Brazil (Marié 2017).

\section{Brazil's cultural diplomacy in Africa}

Culture - as a diplomatic instrument of foreign policy - provides states with facilities for their international insertion, resulting in the demarcation of diplomatic axes, like it was done in the global ambit during the Lula government ${ }^{3}$ (Bijos 2014).

\footnotetext{
${ }^{3}$ Differently, a Brazilian university professor judged that Brazil's cultural diplomacy under Lula was rhetorical rather than effective. / Interview by the author in August 2018
} 
A diplomat in the Brazilian Ministry of Culture's International Relations Department stated:

"the perception of Brazil's culture - that is generally positive - in the foreigner's eye is an asset to get closer to other countries and to open doors as a platform for the country's international insertion. The effects of Brazil's presence in the imaginary of other peoples through culture spread to other domains. Culture is thus directly linked to and inseparable from soft power; Brazil's capacity of influence in the international ambit must take culture into consideration". ${ }^{4}$

For a diplomat of an African country posted in Brazil, "cultural diplomacy plays an important role in Brazil's assertion in the world, based on a very positive image abroad $^{5}$ that attenuates the negative effect of internal difficulties. The impact of cultural diplomacy is very important for any country, but it is particularly evident in Brazil's case" ". The Lula administration encouraged Brazil's global insertion taking into account the cultural dimension because of the centrality of culture in international relations. The resources granted to the Cultural Department of the Ministry of External Relations increased significantly, elevating the level of expenses to one fairly superior to those observed under President Fernando Henrique Cardoso.' Also, the range of partners in the domain of cultural diplomacy widened in line with Brazil's foreign policy axes, and relations with developing countries - especially African nations - were amplified (Marié 2017). Indeed, during Lula's presidency, the consolidation of cultural diplomacy towards African countries represented a fundamental element of Brazil's African policy. This paper will present Brazilian initiatives on the African

\footnotetext{
${ }^{4}$ Interview by the author in June 2018

${ }^{5}$ As an example, culture makes the integration of Brazilians abroad easier, since people in host countries have a positive opinion of Brazilians.

${ }^{6}$ Interview by the author in July 2018

${ }^{7}$ The executed budget of the Cultural Department (Ministry of External Relations) equalled R\$2.07 million in 2003 and reached $\mathrm{R} \$ 9.01$ million in 2010. This also represented an increase in the total budget executed by the Ministry of External Relations: $0.17 \%$ in 2003, a peak 0.5\% in 2009 and $0.43 \%$ in 2010 . The resources of the Ministry of Culture's International Relations Department equalled R\$5.9 million in 2009 and reached $R \$ 16.3$ million in 2010.
} 
continent in three domains of cultural diplomacy: cultural and language diffusion, as well as educational cooperation.

\section{Cultural diffusion}

In accordance with Brazil's foreign policy under President Lula, greatest prominence was given to cultural diffusion in Africa. Several initiatives illustrate the resort to cultural diplomacy as an instrument of Brazil's foreign policy, in addition to numerous agreements signed, in particular with countries of the Portuguese-speaking Commu-

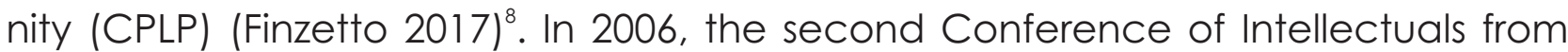
Africa and the Diaspora was held in Salvador (State of Bahia), city with the largest population of afro-descendants in Brazil. In the past ten years, the city of Rio de Janeiro has hosted the Theatre Festival of Portuguese Language (FESTLIP) that offers a framework of exchanges and activities for artists from Portuguese-speaking countries. Brazil launched in 2010 a project called DOCTV CPLP of coproduction and diffusion of audio-visual documentaries throughout the world for member countries of the Community of Portuguese-speaking countries. In May 2010, President Lula inaugurated the cabled chain TV Brasil Internacional, broadcasting Brazilian programmes in 49 African countries to promote a positive image of the country.

The Ministry of Culture's involvement also actively participated in the promotion of the Brazilian culture abroad during Lula's presidency, enabling the growing presence and prestige of Brazil and the Brazilian culture abroad. The Ministry of Culture showed its willingness to partake in Brazil's international cultural standing through its participation in the organisation of the Pan African Contemporary Art Exhibition in 2005 and the Conference of Intellectuals from Africa and the Diaspora in 2006, as well as its efforts for the diffusion of Afro-Brazilian culture through the cultural foundation, Palmares (Falomir Lockhart and Lamine Sarr 2015).

\footnotetext{
${ }^{8}$ Investments in African countries were below the investments of other groups of countries. According to a diplomat from an African country, despite historical, social and demographic proximity, and an attempt during the Lula years for greater approximation, Brazil's presence and cultural action on the African continent are not commensurate to its global aspirations. / Interview by the author in July 2018
} 


\section{Language diffusion}

Language is the most salient feature of the culture of a people and the most "inherent characteristic of a nation" since, according to Babiniotis, "there is no way, more direct, more substantial, no shorter way to get to know a people than by learning their language. The language of a people is the way they conceive, classify and express the world" (Kitsou 2013). A diplomat from the Cultural Department of the Ministry of External Relations asserted: "language diffusion is one the axes of Brazil's cultural diffusion, which clearly became a more fundamental foreign policy instrument of enormous utility throughout the years and enabled Brazil to project itself a good deal". . During President Lula's government, it was required that $70 \%$ of the Cultural Department's budget for the diffusion of the Portuguese language of the Brazilian Ministry of External Relations should be used for priority areas of Brazil's foreign policy, including Africa in third position after South America and Latin America. Africa, which counts six centres (South Africa', Angola, Cabo Verde, Guinea-Bissau, Mozambique and São Tomé and Principe) out of 24 worldwide, is the second region hosting the most Brazilian cultural centres (CCB) after Latin America and the Caribbean (13 centres). These centres, which are part of the cultural departments of the diplomatic representations abroad, are important instruments to the perpetration of Brazil's cultural policy abroad. They play a fundamental role in Brazil's promotion in Africa by offering Portuguese language courses and workshops on the Brazilian culture through music, dance and literature. Their action is complemented by Brazilian studies centres, teaching units offering Portuguese classes, and different readership networks gathering specialist professors sent to universities abroad to promote the Brazilian language and culture. The readership programme was identified as a successful modality: the number of Brazilian readers worldwide grew from 40 in 30 countries in

\footnotetext{
${ }^{9}$ Interview by the author in June 2018

${ }^{10}$ Inside the grouping, leaders expressed consideration for cultural collaboration since the $2^{\text {nd }} B R I C$ summit in 2010. This proposal was then formalized in the Agreement on Cooperation in the Field of Culture in 2015 and led to the formation of the Cultural Action Plan in 2017. In the cultural agreement, they are "convinced that cultural dialogue contributes to the progress of nations and better mutual understanding of cultures, facilitating rapprochement of peoples" (Nort 2018). 
2006 to 52 readers in 44 states six years later, with a network of close to 6,000 students. Three African countries in 2003 (Ivory Coast, Ghana and Senegal) and nine countries in 2010 (Benin, Cameroun, Gabon, Ghana, Guinea-Bissau, Kenya, Nigeria, Mozambique and São Tomé and Principe) hosted Brazilian invited professors (Falomir Lockhart and Lamine Sarr 2015; Machado 2012).

\section{Educational cooperation}

In the domain of education, the Lula administration was also at the origin of several projects. The Federal University of Luso-Afro-Brazilian Integration (Unilab) was created in 2010, partly financed by the Federal Government. Inaugurated in May 2011 , on the occasion of Africa Day, the university is located in the city of Redenção (State of Ceará), the first Brazilian city to abolish slavery in 1883. According to Cervo (2008), "a relevant contribution to build the professional and scientific capacities is taking place, as numerous young Africans are present in Brazilian universities". In fact, Arrosa Soares (2009) stressed that Brazil developed a programme of great relevance in the field of cultural diplomacy, i.e. scholarship awards for African students to pursue high-education courses in Brazilian universities through the graduation (PEC-G) and post-graduation (PEC-PG) covenants. The Brazilian government delivered scholarships to numerous African students in order for them to obtain a higher education degree of good quality and to contribute to their country's development on their return. The PEC-G was launched in 1965, and out of 57 countries participating in the programme in 2015, there were 25 African states; Portuguese-speaking partners are the most important beneficiaries of this programme (e.g. Cabo Verde, 2,933 students over 2000-2015 and Guinea-Bissau, 1,336 students). The PEC-PG, launched in 1981 and updated in 2006, benefits 24 African countries and $20 \%$ of beneficiaries come from the African continent (compared to 75\% from Latin America and the Caribbean). Between 2003 and 2010, 4,300 African graduate students from 20 countries and 237 post-graduate students from 14 countries received scholarships through these two programmes (Falomir Lockhart and LamineSarr 2015). ForMachado (2012), 
these programmes are important instruments for Brazil's cultural diplomacy: they promote a positive image of Brazil through the training of developing countries' future elites and encourage a privileged relation between Brazil and the African continent, which fits within the logic of Brazil's foreign policy insertion through South-South cooperation.

\section{Final remarks}

Hirst and Lima (2006) affirmed that Brazil's desire to obtain international influence and to be considered a major player has been understood principally in terms of its soft power. Brazil has been rising to become an increasingly influential actor on the global scene, by successfully profiling itself as a benevolent power, thanks to its foreign policy's effectiveness to advance its global status through soft power (Marthoz 201 1; Soares Castro 2013). During Lula's mandate, culture was considered a key foreign policy axis (Marié 2017). Indeed, Brazil's foreign policy - using cultural diplomacy as a tool - made an enormous move forward on the question of international promotion (Bijos and Arruda 2012). Also, Brazil's approximation to Africa including through amplified relations in the domain of cultural diplomacy - inserts itself into a strategy of consolidation of South-South relations, an essential component of Brazil's international ascension programmes (Falomir Lockhart and Lamine Sarr 2015).

\section{Bibliographic references}

ABDENUR, Adriana, Danilo Marcondes. "Democratization by association? Brazil's social policy cooperation in Africa". Cambridge Review of International Affairs 29, no.4 (2016): 1542-1560.

AMORIM, Celso. "Brazilian Foreign Policy under President Lula (2003-2010): an overview". Revista Brasileira de Politica Internacional 53 (2010): 214-240. 
ARROSA SOARES, Maria Susana. "Diplomacia cultural and diplomacia militar: o caso brasileiro". Estudios Avanzados 12 (2009): 43-52.

BIJOS, Leila. "A Relevância da Diplomacia Cultural Brasileira no Cenário Internacional". Blogs Foreign and Commonwealth Office, 2014. https://blogs.fco.gov.uk/pt-br/luanaseabra/2014/01/03/a-relevancia-da-diplomaciacultural-brasileira-guest-blog-por-leila-bijos/

BIJOS, Leila, Verônica Arruda. "A diplomacia cultural como instrumento de política externa brasileira". In Relações internacionais, gestão do conhecimento e estratégias de desenvolvimento: debates interdisciplinares na primeira década do novo milênio, edited by Nilzo Ivo Ladwig and Rogério Santos da Costa, 165184. Palhoça: Editora Unisul, 2012.

BIJOS, Leila, Verônica Arruda. "A diplomacia cultural como instrumento de política externa brasileira". Revista Dialogos 13, no.1 (2010): 33-53.

BRIMMER, Esther. "Is Brazil a 'Responsible Stakeholder' or a Naysayer?" The Washington Quarterly 37, no.3 (2014): 135-151.

BRUK, Boris. "Attract and Rule? Lessons of Soft Power from BRICS Countries". IMR, 2013. http://imrussia.org/en/politics/439-attract-and-rule-lessons-of-soft-power-from-brics

BUSS, Paulo, José Roberto Ferreira. "Brasil e saúde global". In Política externa brasileira a política das práticas e as práticas da política, edited by Leticia Pinheiro and Carlos Milani, 241-268. Rio de Janeiro: Editora FGV, 2012.

CARDOSO, Fernando Henrique. A soma e o resto um olhar sobre a vida aos 80 anos. Rio de Janeiro: Civilização Brasileira, 2011.

CERVO, Amado Luiz. Inserção Internacional: formação de conceitos brasileiros. São Paulo: Saraiva, 2008.

CHATIN, Mathilde. Brazil: a new powerhouse without military strength? A conceptual and empirical quest about an emerging economic power. Brasilia: FUNAG, 2018.

CUMMINGS, Milton. Cultural Diplomacy and the United States Government: A Survey. Washington D.C.: Center for Arts and Culture, 2003.

DYTZ FILHO, Nilo. Crise e reforma da UNESCO: reflexões sobre a promoção do poder brando do Brasil no plano international. Brasília: FUNAG, 2014.

FALOMIR LOCKHART, Nicolás, Mamadou Lamine Sarr. "La place de la diplomatie culturelle dans la politique africaine du Brésil et du Venezuela". Cahiers des Amériques latines 80 (2015): 109-125. 
FINZETTO, Yves Carneiro. Difusão da cultura brasileira no exterior: a Divisão de Operações de Difusão Cultural do Itamaraty no governo Lula. Master's Thesis (University of São Paulo), 2017.

GARDINI, Gian Luca. "Brazil: What Rise of What Power?" Bulleting of Latin American Research 35, no.1 (2015): 5-19.

HIRST, Mônica, Maria Regina Soares de Lima. "Brazil as an intermediate state and regional power: action, choice and responsibilities". International Affairs 82, no.1 (2006): 21-40.

KALIL, Mariana, Jacqueline Braveboy-Wagner. "Brazil's International Rise in the Twenty-First Century: Ambitions and Difficulties". In Diplomatic Strategies of the Global South, edited by Jacqueline Braveboy-Wagner, 27-58. Basingstoke: Palgrave Macmillan, 2016.

KITSOU, Stephen. "The Power of Culture in Diplomacy: The Case of US Cultural Diplomacy in France and Germany". The Journal of Public Diplomacy 2, no. 1 (2013): 21-39.

LEE, Sook Jong. "South Korean Soft Power and How South Korea Views the Soft Power of Others". In Public Diplomacy and Soft Power in East Asia, edited by Sook Jong Lee and Jan Melissen, 139-162. Basingstoke: Palgrave Macmillan, 2011.

LEITE LESSA, Mônica, Miriam Gomes Saraiva, Dhiego Moura Mapa. "Entre o Palácio Itamaraty e o Palácio Capanema: perspectivas e desafios de uma diplomacia cultural no governo Lula". In Política externa brasileira a política das práticas e as práticas da política, edited by Leticia Pinheiro and Carlos Milani, 95120. Rio de Janeiro: Editora FGV, 2012.

LIMA, Ana Paula. "Entrevista Celso Amorim". Revista Sapientia 24, no.4 (2015): 511.

LULA INSTITUTE. "Governo Lula iniciou processo inédito de aproximação com países da África" 2017 http://www.institutolula.org/governo-lula-iniciou-processoinedito-de-aproximacao-com-paises-da-africa

LUSTIG, Robin. "Brazil emerges as a leading exponent of 'soft power'". BBC, 2010 http://news.bbc.co.uk/2/hi/americas/8580560.stm

MACHADO, Gabriel Luiz. A difusão cultural brasileira como instrumento de política externa: estratégias contemporâneas. PhD Thesis (Federal University of Rio Grande do Sul), 2012. 
MARES, David. "Brazil: revising the status quo with soft power?" In Accommodating Rising Powers: Past, Present and Future, edited by Thazha Varkey Paul, 246-267. Cambridge: Cambridge University Press, 2016.

MARIÉ, Solène. "As Políticas de Diplomacia Cultural nas Gestões Cardoso e Lula em perspectiva comparada". In Dossiê cultura em foco: integração cultural latino-americana, edited by Bruno Alves Marcelino, 85-106. Jaguarão : Editora CLAEC, 2017.

MARQUES, Joseph, Anthony Spanakos. "South-South relations and the English School of International Relations: Chinese and Brazilian ideas and involvement in Sub-Saharan Africa". Revista Brasileira de Política Internacional 57 (2014): 138-156.

MARSILI, Marco. "Brazil: the Carambole Strategy of a Rising Power". Universities: Relações Internacionais 13, no.1 (2015): 63-83.

MARTHOZ, Jean-Paul. "Turkey and Brazil - keepers of peace". The Broker, 2011 http://www.thebrokeronline.eu/Blogs/Emerged-powers-in-the-21st-century/Turkey-andBrazil-keepers-of-peace

MINISTRY OF EXTERNAL RELATIONS. "Cultural Diplomacy", n.d. http://www.itamaraty.gov.br/pt-BR/diplomacia-cultural

NORT (VAN), Carolijn (2018) "BRICS issue-narrative on culture: strategic or trivial?" International Journal of Cultural Policy 24, no.6 (2018): 786-797.

NYE, Joseph. Soft power: the means and success in world politics. New York: Public Affairs, 2004.

NYE, Joseph. (2010) "Soft power and Cultural Diplomacy". Public Diplomacy Magazine, 120-124.

NYE, Joseph. The Future of Power. New York: Public Affairs, 2011.

NYE, Joseph. Is The American Century Over? Cambridge: Polity Press, 2015.

RODRIGUEZ, Júlio. Os efeitos de limitadas capacidades materiais na politica externa de pôtencias intermediarias do sistema internacional. PhD Thesis (University of Lisbon), 2013.

SANTANDER, Sebastian. "La coopération brésilienne avec l'Afrique". Revue défense nationale 738 (2011): 37-44.

SATANA, Nil. "Multilateral interventions as a power-enhancing instrument: Rising powers' path from the periphery to the center". In Brazil as a Rising Power, edited by Philip Cunliffe and Kai Kenkel, 127-146. London: Routledge, 2016. 
SEABRA, Pedro. "A harder edge: reframing Brazil's power relation with Africa". Revista Brasileira Política Internacional 57, no.1 (2014): 77-97.

SMITS, Yolanda. "Brazil country report, preparatory action 'Culture in the EU's External Relations'". Digital edition, 2014.

SOARES E CASTRO, Andreia. "Fifa World Cup and 2016 Olympic Games: Brazil's strategy 'to win hearts and minds' through sports and football". Public Diplomacy Magazine (2013): 28-35.

STOLTE, Cristina. "Brazil's South-South Cooperation with Africa 2003-2013: a decade of Brazilian outreach towards its Atlantic neighbourhood". CEBRI Artigos 2, no.9 (2014): 7-21.

THÉRY, Hervé. Le Brésil Pays Emergé. Paris: Armand Colin, 2014.

VIDAL PÉREZ, Luis Antonio. Pop power: Pop Diplomacy for a Global Society. Digital edition, 2014. 